\title{
Children who develop allergy have low fecal alpha-defensin levels but high beta-defensin levels in infancy
}

\author{
Emma Savilahti*, Anna Kaarina Kukkonen, Tari Haahtela, Mikael Kuitunen, Erkki Savilahti \\ From Food Allergy and Anaphylaxis Meeting 2011 \\ Venice, Italy. 17-19 February 2011
}

\section{Background}

Since early innate immunity responses and the intestinal flora guide adaptive immune responses, we investigated whether fecal defensin levels in infancy were associated with the emergence of allergy.

\section{Methods}

In a randomized, double-blind placebo-controlled trial, 1018 infants in high risk for allergy received from birth to 6 months either a mixture of pre- and probiotics, or placebo. They were followed for the emergence of allergic diseases and sensitisation for 5 years. In an unselected group of 48 infants receiving probiotics and 52 receiving placebo, we measured fecal levels of human neutrophil peptide (HNP) 1-3, $\beta$-defensin 2 (HBD2) with enzyme linked immunosorbent assays (ELISA) at the age of 3 and 6 months. TNF- $\alpha$ and calprotectin had been measured with ELISA, and $\alpha 1$-antitrypsin with an immunodiffusion method in a proportion of samples.

\section{Results}

Fecal levels of HNP1-3 and HBD2 decreased from 3 to 6 months. Low HNP1-3 and high HBD2 levels at 6 months were associated with allergy and sensitisation by the age of 5 years $(\mathrm{p}<0.05)$. HNP1-3 levels correlated negatively with $\alpha 1$-antitrypsin levels at the age of 3 months (coefficient $-0.5 ; \mathrm{p}<0.05$ ) in children who developed sensitisation only or combined with allergic disorders. HBD2 levels correlated positively with TNF- $\alpha$ (0.7; $\mathrm{p}<0.05)$ in children with subsequent IgE-mediated allergy. Probiotic treatment tended $(\mathrm{p}<0.06)$ to increase fecal HBD2 levels at the age of 6 months compared with placebo.

University of Helsinki, Helsinki, Finland

(C) 2011 Savilahti et al; licensee BioMed Central Ltd. This is an open access article distributed under the terms of the Creative Commons Attribution License (http://creativecommons.org/licenses/by/2.0), which permits unrestricted use, distribution, and reproduction in any medium, provided the original work is properly cited.

\section{Conclusions}

Early innate immunity responses in the gut are associated with the emergence of allergy later in childhood.

Published: 12 August 2011

doi:10.1186/2045-7022-1-S1-O32

Cite this article as: Savilahti et al:: Children who develop allergy have low fecal alpha-defensin levels but high beta-defensin levels in infancy. Clinical and Translational Allergy 2011 1(Suppl 1):032.
Submit your next manuscript to BioMed Central and take full advantage of:

- Convenient online submission

- Thorough peer review

- No space constraints or color figure charges

- Immediate publication on acceptance

- Inclusion in PubMed, CAS, Scopus and Google Scholar

- Research which is freely available for redistribution

\section{Biomed Central}

